\title{
EVALUATION OF CYTOTOXICITY AND EXPRESSION OF CASPASE-3 AND P53 IN HCT-116 CELLS OF LINEAGE TREATED WITH DIFFERENT EXTRACTS OF Euphorbia tirucalli L.
}

(Avaliação da citotoxicidade e expressão de caspase-3 e p-53 em células da linhagem HCT-116 tradatas com diferentes extratos de Euphorbia tirucalli L.)

Anderson Barros Archanjo ${ }^{1}$, Francisco de Paula Careta, Adilson Vidal Costa, Louisiane Carvalho Nunes

\footnotetext{
${ }^{1}$ Correspondência: andersonarchanjo@gmail.com
}

RESUMO: Euphorbia tirucalli é uma planta conhecida como aveloz que tem sido utilizada na terapia anticâncer com pouca comprovação científica. Objetivou-se avaliar a eficácia in vitro do potencial citotóxico de extratos de aveloz sobre células de linhagem tumoral. Foram preparados os extratos hexânico e hidroalcoólico em diferentes concentrações. Após $96 \mathrm{~h}$ foi verificada a viabilidade celular e a taxa de apoptose (p53 e caspase-3). O extrato hexânico revelou maior citotoxicidade na linhagem HCT-116 em concentrações acima de $125 \mu \mathrm{g} / \mathrm{mL}$ enquanto que o hidroalcoólico acima de $500 \mu \mathrm{g} / \mathrm{mL}$. A CL50 para o extrato hexânico foi de 60,2873 $\mu \mathrm{g} / \mathrm{mL}$ e hidroalcoólico foi de $100,6066 \mu \mathrm{g} / \mathrm{mL}$. Houve diferença significativa entre a média de células marcadas com p53 nas concentrações de $500 \mu \mathrm{g} / \mathrm{mL}, 250 \mu \mathrm{g} / \mathrm{mL}$ e $62,5 \mu \mathrm{g} / \mathrm{mL}$ e entre a média de células caspase-3 positivas nas concentrações de $500 \mu \mathrm{g} / \mathrm{mL}, 125 \mu \mathrm{g} / \mathrm{mL}$ e $62,5 \mu \mathrm{g} / \mathrm{mL}$, observando-se maior eficácia do extrato hidroalcoólico. Os dados obtidos fornecem evidências do potencial citotóxico in vitro dos extratos hidroalcoólico e hexânico de aveloz em linhagem HCT-116. Houve aumento da expressão de caspase-3 e p53 nas células da linhagem tumoral expostas aos extratos hidroalcoólico e hexânico de E. tirucalli.

Palavras-chave: apoptose; cultivo cellular; Euphorbiaceae; imunocitoquímica; terapia anticâncer

ABSTRACT: Euphorbia tirucalli, a plant commonly known as aveloz, has been employed in anticancer therapy with little scientific proof. The goal of this study was to evaluate the cytotoxic potential and expression of caspase-3 and p53 in colorectal cancer cell lines treated with aveloz extracts. Hexanic and hydroalcoholic extracts were prepared in different concentrations. After $96 \mathrm{~h}$, cell viability and apoptosis rate (p53 and caspase-3 expression) were verified. The hexanic extract revealed higher cytotoxicity on HCT-116 cell line at concentrations above $125 \mu \mathrm{g} / \mathrm{mL}$, and hydroalcoholic extract above $500 \mu \mathrm{g} / \mathrm{mL}$. LC 50 for the hexanic extract was 60.2873 $\mu \mathrm{g} / \mathrm{mL}$, and for hydroalcoholic extract $100.6066 \mu \mathrm{g} / \mathrm{mL}$. There were significant differences among the averages of cells marked with p53 at the concentrations 62.5, 250 and $500 \mu \mathrm{g} / \mathrm{mL}$, as well as among the averages of caspase-3-positive cells at the concentrations $62.5,125$ and $500 \mu \mathrm{g} / \mathrm{mL}$, with higher cytotoxic effect being observed for the hydroalcoholic extract. The obtained data provides evidence for the cytotoxic potential in vitro of the hydroalcoholic and hexanic extracts of aveloz on HCT-116 cell line. There was an increase in the expression of caspase- 3 and p53 in the tumor line cells exposed to extracts of E. tirucalli.

Key Words: anticancer therapy; apoptosis; cell culture; Euphorbiaceae; immunocytochemistry 


\section{INTRODUCTION}

Natural products extracted from plants have played an important role in the process of discovering pharmaceuticals, be it as structural models for the synthesis of new molecules or owing to their pharmacological properties (Vale e Orlanda, 2011).

Among the many plants recently studied is Euphorbia tirucalli Linneau, commonly known as aveloz or firestick plant, which belongs to the Euphorbiaceae family. It is a semiligneous shrub originating from Africa and brought to Brazil for ornamental purposes, presenting green, cylindrical and succulent young branches, and barely visible leaves and flowers, which fall soon after emerging (Avelar, 2010).

Aveloz has been used in popular medicine since the beginning of this century in anticancer therapy and homeopathic practice, and is currently still employed as complementary therapy in cancer treatment (Oliveira e Nepomuceno, 2004).

Phorbol esters, which can be found in E. tirucalli, are known to be active in biological processes such as inflammation and modulation of cytokine expression (Smith et al, 1998; Bishayi e Samanta 2002). Studied biological activity of some terpenes has also been shown to induce apoptosis in tumor cells as well as to modulate the expression of resistance to multiple drugs (Abdelgaleil et al, 2001; Duarte et al, 2009)

The terpenes present in the latex of this plant are phorbol esters, euphol and ingenols, and flavonoids. Phorbol esters with a tiglian nucleus found in the plant are considered responsible for its high toxicity (Varricchio et al. 2008), and have been clinically documented as tumor promoters. However, diterpenes with ingenane nucleus (ingenols) present in the latex composition exhibit anticancer activity, causing significant inhibition of protein kinase $C$ (PKC) proliferation, which results in an antiproliferative and apoptotic effect in various human cancer cells (Sapiência 2009).

Varricchio et al. (2008) cited a study on the antitumoral activity of $E$. tirucalli $\mathrm{L}$. in mammary gland 256 tumors (Walker tumor) of female rats, verifying that, at low dosages (100 mg to 400 $\mathrm{mg} / \mathrm{kg}$ ), the extract did not reduce the tumor volumes, and at high dosages $(1,000 \mathrm{mg} / \mathrm{kg})$ it induced or stimulated tumor growth in female rats. In addition, high toxicity was verified when the extract was administered parenterally, while being almost atoxic when given orally.

Granja (2003) performed a similar experiment with guinea pigs inoculated with cells of Ehrlich tumor (mammary tumor) to evaluate the animals' survival after five days of treatment. The results demonstrated increased survival of six and eight days in treated animals in comparison to the control.

Betancur-Galvis et al. (2002) evaluated 47 extracts in ten species from the genus Euphorbia which were tested in vitro with regards to their antitumoral (antiproliferative and cytotoxic) potential and anti-herpetic activity. Five of the 47 extracts (11\%), representing three of the ten species (30\%), exhibited anti-herpetic activity, which was highest in aqueous methanol extracts from stem and leaf of $E$. cotinifolia; however, these extracts did 
not exhibit cytotoxicity. Six extracts $(13 \%)$, representing four species $(40 \%)$, demonstrated cytotoxic activity, which was highest in the dichloromethane extract obtained from leaves of $E$. cotinifolia.

The application of immunological assays in histopathological studies has greatly incremented the diagnosis of human neoplasms, being now definitely incorporated to the routine of pathology laboratories (Alves et al. 1999).

Tumor development is determined by three main factors: stage of the cell cycle, percentage of proliferating cells, and number of lost cells. This way, in addition to markers of cell proliferation, apoptosis is also a relevant index in evaluating the biological behavior of neoplasms (Phillips et al. 2000).

One of the methods to quantify the frequency of tumor cells undergoing apoptosis is to evaluate the expression of some enzymes directly related to the apoptotic event, the so-called caspases. Caspases are present in the cytoplasm of most cells, in inactive forms showing a single polypeptide chain; they are activated when this chain is broken, which leads to apoptosis (Robert e Friedlander 2003). Of the over a dozen isoforms of caspases, approximately two thirds present function in the apoptotic process. Two types of caspases act on the apoptosis signaling pathway, being denominated initiators (caspases 8, 9 and 10) and effectors or executors (caspases 3, 6 and 7) (Thormberry $\mathrm{e}$ Lazebnik 1998) Of these, caspase-3 is the most studied (Donoghue et al. 1999; Dukers et al. 2002).

Another histochemical assay related to apoptosis is marking the mutant protein p53 in neoplastic cells
(Alves et al. 1999). p53 is a tumor suppressor gene located on chromosome 17, and the protein it codes acts on cell growth, DNA repair and synthesis, cell differentiation and apoptosis. The functional inactivation of p53 is one of the most common alterations in various neoplasms. The mutations lead to alterations of the coded proteins, which start showing a higher half-life, accumulate in neoplastic cells, and can be detected by immunohistochemical technique (Suzano 2007).

In view of all this, it can be noted that there are few scientific studies corroborating the antitumoral properties of $E$. tirucalli $\mathrm{L}$. The use of natural plant extracts may be a viable alternative in anticancer therapy; moreover, it is possible that these products cause fewer side effects in patients. Hence, new studies are necessary in order to assess the antitumor potential of $E$. tirucalli $\mathrm{L}$. in the tumor therapy of animals and humans. In this context, the present work aimed at evaluating the cytotoxic potential in vitro of $E$. tirucalli extract on colon cancer line cells, with the purpose of discovering new therapeutic strategies to fight cancer in animals and humans.

\section{MATERIAL AND METHODS}

\section{Preparation of Euphorbia tirucalli extracts}

Extract preparation took place at the Laboratory of Phytochemicals and Synthesis of New Compounds at the Agronomic Sciences Center of the Federal University of Espírito Santo (CCA-UFES). The aerial parts of the aveloz (E. tirucalli) were collected at the 
city of Alegre, Espírito Santo (Brazil), being at first identified by botanic analysis and deposited at the Herbarium VIES - Sector Jerônimo Monteiro, under the register VIES 31807. The material was maintained in forced-air incubator at $40^{\circ} \mathrm{C}$ for $72 \mathrm{~h}$, and subsequently ground in cutting mill with $0.8 \mathrm{~mm}$ sieve and stored in air-tight plastic containers.

For obtaining of the extracts, the plant material powder (100 g) was transferred to Erlenmeyer flasks containing the liquid extractors for a period of $72 \mathrm{~h}$. Next, the mixtures were filtered through voile fabric and filter paper. The solution extractive was collected in a volumetric flask, and the volume was filled up to $1000 \mathrm{~mL}$ with the liquid extractor. The same liquid was added to the macerated sample, in which it also rested for $72 \mathrm{~h}$. This process was repeated three times. The solution extractive was taken to rotating evaporator in a water bath to $45^{\circ} \mathrm{C}(-600$ $\mathrm{ml} / \mathrm{Hg}$ ) for obtaining the extract by liquid extractor removal. The liquid extractors used were hexane and $70 \%$ ethanol.

The extracts were diluted in dimethyl sulfoxide (DMSO) at concentrations of $62.5,125,250,500$, and $1000 \mu \mathrm{g} / \mathrm{mL}$. After the dilutions, the extracts were applied to culture cells in a proportion of $1000 \mu \mathrm{g}$ of cells for each $1.0 \mathrm{~mL}$ of extract, following a methodology similar to that described by Betancur-Galvis et al. (2002).

\section{Cell culture}

The cell line used in this study was HCT-116 (human colorectal carcinoma). This step was developed at the Laboratory of Cell Culture at CCAUFES.
The cell line was routinely cultured in Dulbecco's Modified Eagle Medium (DMEM) with $10 \%$ fetal bovine serum in $75 \mathrm{~cm}^{2}$ polyethylene culture flasks, at a mean density of $1 \times 10^{6}$ cells $/ \mathrm{mL}$, at $37^{\circ} \mathrm{C}$, $5 \% \quad \mathrm{CO}_{2}$, and $90 \%$ humidity, until reaching confluence. Viable cells were counted using a Neubauer chamber by trypan blue assay. Afterwards confluence, the cells were trypsinized using trypsin at a concentration of $10 \mathrm{x}$, cultured on plaques with 24 wells at a density of $6 \times 10^{4}$ cells $/ \mathrm{mL}$, and maintained under the same, just described conditions.

The plant extracts were applied to cells in duplicates, and DMSO was used as negative control. After $96 \mathrm{~h}$, the cells were trypsinized, using only cold medium to cell culture and cell viability was verified.

\section{Cell viability}

For determining cell viability count of viable and non-viable cells in a Neubauer chamber was taken. After the cells were trypsinized, they were resuspended in $200 \mu \mathrm{L}$ medium to cell culture. An aliquot was removed from 10 $\mu \mathrm{L}$ of the above suspension and diluted with $10 \mu \mathrm{L}$ solution of trypan blue, leaving a dilution of $1: 1$. Filled to a Neubauer chamber with dilute solution and proceeded to count the cells. Viable cells are transparent in the presence of the dye while non-viable stained in shades of blue. Four quadrants were counted and taken the average number of viable and non-viable cells.

\section{Apoptosis test}

The apoptotic indexes were evaluated by immunocytochemical marking with the biomarkers p53 and 
caspase-3; the technique was carried out at the Laboratory of Animal Pathology at CCA-UFES. For this end, $75 \mu \mathrm{L}$ of the medium containing the cells recovered from each of the wells of the previous experiment were placed on slides using a cytocentrifuge for six minutes at $1500 \mathrm{rpm}$. After this process, the slides were fixed with absolute ethanol, and stored until the immunomarking procedure. Next, blockage of endogenous peroxidases and antigen recovery were performed. Incubation with the primary antibodies mutant anti-p53 (1:100) and anticaspase-3 (1:200) was carried out after their dilution in solution of $0.1 \%$ bovine serum albumin in Tris buffer, and occurred in moist chamber for $18 \mathrm{~h}$ at $4^{\circ} \mathrm{C}$. Next, the reaction was amplified using a Novolink ${ }^{\mathrm{TM}}$ kit, followed by treatment with 3,3'-diaminobenzidine solution for three minutes at room temperature. The material was counterstained with Harris hematoxylin for five minutes. The slides were next washed under running water for ten minutes, then subjected to the processes of dehydration and assembly in synthetic resin.

For microscopic evaluation of the stained slides by immunocytochemistry, the cells positively marked for each antibody were quantified in five linear fields under $40 \mathrm{x}$ objective, and the average of immunomarked cells was obtained.

\section{Statistical analysis}

Evaluation of cytotoxicity was performed by calculation of $\mathrm{LC}_{50}$ (lethal concentration $50 \%$ ) using the program BioStat 2009 Professional 5.8.4, by means of Probit analysis. To evaluate the expression of p53 and caspase as indicators of apoptosis, test $t$ at $5 \%$ probability was applied.

\section{RESULTS AND DISCUSSION}

The HCT-116 cell line presented excellent growth in culture. With regards to cell morphology, it was observed that, after $96 \mathrm{~h}$, the cells exposed to hexanic extract at concentrations of 62.5 and $125 \mu \mathrm{g} / \mathrm{mL}$ presented discrete and moderate reduction in volume and predominantly rounded morphology. At $250 \mu \mathrm{g} / \mathrm{mL}$, moderate to marked decrease in volume and rounded morphology was detected. Distinctive reduction in volume was seen at the concentration of $500 \mu \mathrm{g} / \mathrm{mL}$, and at 1000 $\mu \mathrm{g} / \mathrm{mL}$ only cell fragments were observed (Figure 1).

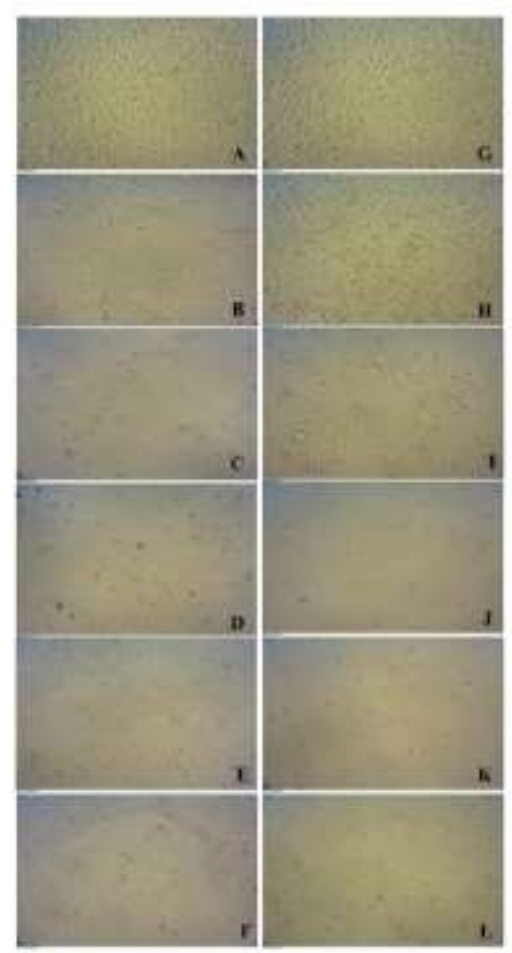

Figure 1 - Phosomicregraphs of HCT-116 cels is culture after geh treament with ertacts of avelor. (A) DMSO; (B) hexanic extract at $62.5 \mu \mathrm{gmL}$ - (C) hexanic extract at $125 \mu \mathrm{g} / \mathrm{mL}$, (D) hexanic extract at $250 \mu \mathrm{g} / \mathrm{mL}$; (E) hexanic extract at $500 \mu g / \mathrm{mL}$; (F) hexanic extract at $1000 \mu \mathrm{gmL}$; (O) DMSO; (H) hydicaicoholic extract at $62.5 \mathrm{\mu g} \mathrm{mL}$ (1) hydroakcoholic extract at $125 \mathrm{pg} \mathrm{mL}$; (J) hydcoalcoholc extract at $250 \mathrm{\mu g} / \mathrm{mL}:(\mathrm{K})$ hydrosicohole extract at $500 \mathrm{\mu g} / \mathrm{mL}$; and (L) hy droalooholis extrast at $1000 \mathrm{\mu g} / \mathrm{mL}$

The cells exposed to hydroalcoholic aveloz extract at the 
concentrations of 62.5 and $125 \mu \mathrm{g} / \mathrm{mL}$ presented a discrete reduction in volume and predominantly rounded morphology. At the concentration of $250 \mu \mathrm{g} / \mathrm{mL}$, a moderate decrease was determined in volume and rounded morphology. At 500 $\mu \mathrm{g} / \mathrm{mL}$, a marked reduction was seen in volume, and at $1000 \mu \mathrm{g} / \mathrm{mL}$ only cell fragments were observed (Figure 1).

Similar studies carried out by Ryu et al. (2013) demonstrated that the use of Ulva fasciata extract induces morphological alterations. Using extract of Garcinia mangostana, Aisha et al. (2012) also verified that the treatment resulted in morphological alterations of cells, characterized by cytoplasmic shrinkage, cell contraction, and polyploidy. These studies corroborate the results found here, as alteration of the individual morphology of the cells was observed. Figures 1 and 2 illustrate the morphology of the cells after $96 \mathrm{~h}$ of treatment with hexanic and hydroalcoholic extracts of aveloz.

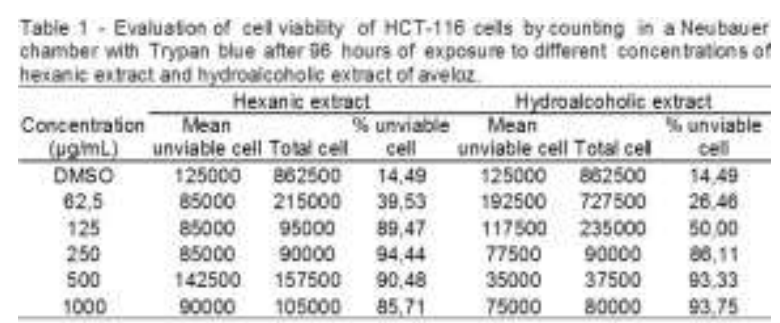

The $\mathrm{LC}_{50}$ value for hexanic extract was $60.2873 \mu \mathrm{g} / \mathrm{mL}$ with standard error of $39.4935 \mu \mathrm{g} / \mathrm{mL}$ by the method of Finney. For the hydroalcoholic extract, the value found was $100.6066 \mu \mathrm{g} / \mathrm{mL}$ with standard error of $0.6023 \mu \mathrm{g} / \mathrm{mL}$, according to the least squares method.

Betancur-Galvis et al. (2002) found a $\mathrm{CC}_{50}$ (cytotoxic concentration $50 \%$ ) of
$222.4 \mathrm{mg} / \mathrm{mL}$, and values higher than $1000 \mathrm{mg} / \mathrm{mL}$ using ethanol and methanol:water as solvents in the preparation of $E$. tirucalli extracts. This way, the cytotoxicity observed by these authors was detected at dosages above those established in the present study. It can be noted that, at low concentrations of both extracts, it was possible to verify high cell mortality. These observed differences may be related to the distinct types of solvent used in the preparation of the extracts.

Choumessi et al. (2012) related that the hydroalcoholic extract of Xylopia aethiopica has antiproliferative activity against a panel of cancer cell lines, being that the $\mathrm{IC}_{50}$ (inhibitory concentration $50 \%$ ) was $2 \mu \mathrm{g} / \mathrm{mL}$ in cells of HCT-116 line. However, studies using extract of Echinops giganteus revealed $\mathrm{IC}_{50}$ of $3.29 \mu \mathrm{g} / \mathrm{mL}$ (Kuet et al. 2013a), and extracts of Crinum zeylanicum and Entada abyssinica yielded values below $10 \mu \mathrm{g} / \mathrm{mL}$ for the same cell line (Kuet et al. 2013b).

This data suggests that the adopted colon cancer cell line may be sensitive to various types of extracts from distinct plant species, but that the solvent used in the extract preparation influences a higher or lower cytotoxicity.

The marking of p53 was observed in HCT-116 cells exposed to both the hexanic and the hydroalcoholic extract, as shown in Figure 2 and Table 2. 




Figure 2-Phohomicrographs of HCT-116 cels immenostained with ant-p53 ater 96 hours of trestment with extroots of aveloz. (A) DMSO; (B) hexaniz extact at 62.8 vgimL: (C) hexanic extract 125 pgimL. (D) hexanic extract 250 ygimL; (E) hexani entract $500 \mathrm{\mu g} / \mathrm{mL}$ : (F) boxanic extract at $1060 \mathrm{pg} / \mathrm{mL}$, (G) OMSO: (H) hydroakoholi. entract at $62.5 \mu \mathrm{g} / \mathrm{mL}$; (1) hydroaicohoic extract at $125 \mu \mathrm{g} / \mathrm{mL}$ : (S) bydroakoholic ortroct at $250 \mathrm{pgimL}$; $(K)$ hydroakcoholic extract at $500 \mathrm{pgimL}$; and $(\Omega)$ hydroakoholis exract at $1000 \mathrm{jg} / \mathrm{mL} \quad 40 \mathrm{x}$

Table 2, Mean vaives of celis maked with p53 after 96 hours of exposure to hesanic extract and bycroalccholic extract of aveloc.

\begin{tabular}{|c|c|c|c|c|c|}
\hline & \multicolumn{2}{|c|}{ Hexanic extract } & \multicolumn{2}{|c|}{ Hydroaicoholic extract } & \\
\hline Concentraton (jug $\mathrm{mL}$ ) & 5 & $D P$ & I & DP & P-value \\
\hline 62.5 & 3 & 10 & 28,8 & 2.8 & $\infty 0001$ \\
\hline 125 & $t$ & 0.7 & 1 & 1,0 & 1,0000 \\
\hline 250 & 2.6 & 0,5 & 5,6 & 1,8 & 0,0261 \\
\hline 500 & 0,6 & 0.9 & 3.2 & 1.3 & 0.0062 \\
\hline 1000 & 5 & 23 & 6.2 & 1.6 & 0,3761 \\
\hline
\end{tabular}

7. mean maked cells, SD. standard deviation ": 5 wdent's t testwith $5 \%$ significance.

Analysis of the data by $t$ test revealed a significant difference between the averages of cells marked with p53 after treatment with either hexanic or hydroalcoholic extract at the concentrations of 500,250 and 62.5 $\mu \mathrm{g} / \mathrm{mL}$; a greater number of immunomarked cells was found in the group treated with hydroalcoholic aveloz extract $(P<0.05)$.

Expression of the protein p53 is related to cell growth, DNA repair and synthesis, cell differentiation, and apoptosis (Suzano 2007). However, its mutant form, which was also used in this study, is frequently associated to the occurrence of apoptosis in neoplastic cells, as described by Alves et al. (1999). This way, it is understood that the expression of p53 observed in the cells used here could indicate that they are undergoing apoptosis, caused by action of the different extracts.

Moreover, it is known that the functional inactivation of p53 is one of the most common alterations in various neoplasias. The mutations lead to alterations in the coded proteins, which start showing higher half-life, accumulate in neoplastic cells, and can be detected by immunohistochemistry (Suzano 2007).

In the present study, also the expression of caspase- 3 on HCT-116 cell line was analyzed. It is known that, at the initial events of apoptosis, depolarization of the mitochondrial membrane occurs, followed by liberation of cytochrome $\mathrm{c}$; this molecule then initiates the activation cascade of caspases, including caspase-3, which acts as an effector of cell death (Elmore 2007).

More than twelve caspase isoforms have already been characterized, with two types acting in the signaling pathway that leads to apoptosis, being denominated initiators (caspases 8, 9 and 10) and effectors or executors (caspases 3, 6 and 7) (Thormberry e Lazebnik 1998). The group of effector caspases is the most relevant, seeing that after activation of these proteins, the mechanism of apoptosis activation becomes irreversible. Active caspase-3 also participates in the cleavage process of various enzymes involved in DNA repair, cell cycle, cytoskeleton formation, 
and nuclear organization (Chang e Yang 2000; Grutter 2000).

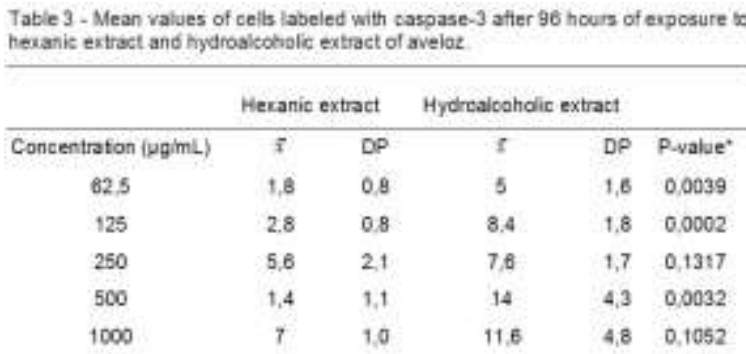

F: mean maked cells. SO: standard deviation": Swdents t testwo $5 \%$ significance



Figure 3 - Photomicrographs of HCT-116 cells immunostained with anti -caspase 3 antibody after geh treatment with extracts of aveloz. (A) DMSO, (B) hexanic extract a $2.5 \mathrm{\mu gmL}$ (C) hexanic extract at $125 \mathrm{\mu g} \mathrm{mL}$; (D) hexanic extract at $250 \mathrm{\mu g} \mathrm{mL}$; (E exanic extract at $500 \mathrm{pg} / \mathrm{mL}$; (F) hexanic extraet at 1000 pgimb; (G) DMSO; (H) ydroakcholic extract at $62.5 \mathrm{ggmL} ;$ i) hydroaicoholic extract at $125 \mathrm{pg} / \mathrm{mL} ;$ (J) bydroakcholic entract at $250 \mathrm{\mu g} / \mathrm{mL} ;(K)$ hydroalcoholic ortract at $\$ 00 \mathrm{\mu g} / \mathrm{mL}$; and (L) fydroalcobolic extract at $500 \mu \mathrm{gimL}$. $40 x$

Analysis of the data by $t$ test showed significant differences between the averages of cells immunomarked by caspase-3 exposed to either hexanic or hydroalcoholic extracts at concentrations of $62.5,125$ and $500 \mu \mathrm{g} / \mathrm{mL}$; a higher number of cells positive for caspase- 3 was found in the group treated with hydroalcoholic aveloz extract $(\mathrm{P}<0.05)$.

Nishibori et al. (2012) also observed activation of caspase-3 after exposure of HCT-116 line to 'mekabu' extract (Undaria pinnatifida). However, Tsai et al. (2012), using extract from flowers of Echinacea purpurea and cichoric acid, observed that the acid effectively induces apoptosis in colon cancer cells, which was identified by DNA fragmentation, activation of caspase-9, cleavage of PARP (Poly ADP ribose polymerase), and downregulation of beta-catenin.

Ryu et al. (2013) used extract of $U$. fasciata and detected inhibition of $50 \%$ of colon cancer cells at the concentration of $200 \mu \mathrm{g} / \mathrm{mL}$. Besides, they highlighted that a possible inhibition mechanism was the activation of caspase-9 and caspase-3, owing to disturbance of the mitochondrial membrane, and consequent activation of the apoptotic pathway. Du et al. (2012) also observed increase in the activity of caspase- 3 and caspase- 9 in study using panaxadiol, a saponin extracted from American ginseng.

\section{CONCLUSION}

In conclusion, the results of this study provide evidence for the cytotoxic potential in vitro of hydroalcoholic and hexanic extracts of E. tirucalli on cell lines of colorectal carcinoma. Hexanic extract proved to be more efficacious than hydroalcoholic extract. Higher cytotoxic efficacy of the extracts was observed at the highest concentrations, with hexanic extract presenting best efficacy above $125 \mu \mathrm{g} / \mathrm{mL}$, and hydroalcoholic extract above $500 \mu \mathrm{g} / \mathrm{mL}$. An increase was observed in the expression of caspase- 3 and p53 in the tumor line cells exposed to hydroalcoholic and hexanic extracts of E. tirucalli, being more evident in the hydroalcoholic extract. 


\section{ACKNOWLEDGMENT}

We thank the Fundação de Amparo a Pesquisa do Espírito Santo (FAPES) for financial support.

\section{REFERENCES}

ABDELGALEIL, A.A.M.; KASSEM, S.M.I.; DOE, M. et al. 2001. Diterpenoids from Euphorbia paralias. Phytochemistry, v.58, n.7, p.1135-1139, 2001.

AISHA, A.F.A.; ABU-SALAH, K.M.; ISMAIL, Z. et al. In vitro and in vivo anticolon cancer effects of Garcinia mangostana xanthones extract. BMC Complementary and Alternative Medicine, v.12, n.104, 2012.

ALVES, V.A.F.; BACCHI, C.E.; VASSALO, J. Manual de Imunohistoquímica. São Paulo: Sociedade Brasileira de Patologia, 1999.

AVELAR, B.A. Detecção in vitro de citocinas intracitoplasmáticas (interferon gama, fator de necrose tumoral, interleucina 4 e interleucina 10) em leucócitos humanos tratados com extrato bruto diluído de Euphorbia tirucalli. 2010. Diamantina, $79 f$. Dissertação (Mestrado em Ciências Fisiológicas) - Programa Multicêntrico em Ciências Fisiológicas, Universidade Federal dos Vales do Jequitinhonha e Mucuri.

\section{BETANCUR-GALVIS L.A. Cytotoxic and} antiviral activities of Colombian medicinal plant extracts of the Euphorbia genus. Memórias do Instituto Oswaldo Cruz, v.97, n.4, p.541-546, 2002.

BISHAYI, B.; SAMANTA, A.K. Modulation of interleukin-8 receptor expression by lipopolysaccharide (LPS) and phorbol myristate acetate (PMA) in human peripheral monocytes a preliminary study. Indian Journal of Physiology and Pharmacology, v.46, n.4, p.407- 422, 2002.

CHANG, H.Y.; YANG, X. Proteases for cell suicide: functions and regulation of Caspases. Microbiology and Molecular Biology Reviews, v.64, n.4, p.821-846, 2000.

CHOUMESSI, A.T.; DANEL, M.; CHASSAING, S. et al. Characterzation of the antiproliferative activity of Xylopia aethiopica. Cell division, v.7, n.8, 2012.

DONOGHUE, S.; BADEN, H.S.; LAUDER, I. et al. Immunohistochemical localization of Caspase-3 correlates with clinical outcome in B-Cell Diffuse LargeCell Lymphoma. Cancer Research, v.59, p.5386-5391, 1999.

DU, G.; WANG, C.; ZHANG, Z. et al. Caspase-mediated pro-apoptotic interaction of panaxadiol and irinotecan in human colorectal cancer cells. Journal of Pharmacy and Pharmacology, v.64, n.5, p.727-734, 2012.

DUARTE, N.; RAMALHETE, C.; VARGA, A. et al. Multidrug resistance modulation and apoptosis induction of cancer cells by terpenic compounds isolated from Euphorbia species. Anticancer Research, v.29, n.11, p.44674472, 2009.

DUKERS, D.F.; OUDEJANS, J.J.; VOS, W. et al. Apoptosis in B-cell lymphomas and resctive lymphoid tissues always involves activation of caspase- 3 as determined by a new in situ detection method. The Journal of Pathology, v.196, n.3, p.307-315, 2002.

ELMORE, S. Apoptosis: a review of programmed cell death. Journal of Toxicologic Pathology, v.35, n.4, p.495516, 2007. 
GRANJA, S. Efeitos do extrato liofilizado da Euphorbia tirucalli L. sobre a resposta hematopoiética em camundongos portadores do tumor ascítico de Ehrlich. 2010. Campinas, 76f. Dissertação (Mestrado em Farmacologia) - Curso de PósGraduação da Faculdade de Ciências Médicas, Universidade Estadual de Campinas.

GRUTTER, M.G. Caspases: key players in programmed cell death. Current Opinion in Structural Biology, v.10, n.6, p.649-655, 200.

KUET, V.; SANDJO, L.P.; WIENCH, B. et al. Cytotoxicity and modes of action of four Cameroonian dietary spices ethnomedically used to treat Cancers: Echinops giganteus, Kylopia aethiopica, Imperata cylindrical and Piper capense. Journal of Ethnopharmacology, v.149, n.1, p.245-253, 2013a.

KUET, V.; VOUKENG, I.K.; TSOBOU, R. et al. Cytotocity of Elaoephorbia drupifera and other Cameroonian medicinal plants against drug sensitive and multidrug resistant cancer cells. BMC Complementary and Alternative Medicine, v.13, 2013b.

NISHIBORI, N.; ITOH, M.; KASHIWAGI, M. et al. In vitro cytotoxic effect of etanol extract prepared from sporophyll of Undaria pinnatifida on human colorectal câncer cells. Phitotherapy research, v.26, n.2, p.191-196, 2012.

OLIVEIRA, A.P.; NEPOMUCENO, J.C. Evaluation of genotoxic and antigenotoxic effects of the avelos (Euphorbia tirucalli) in Drosophila melanogaster. Bioscience Journal, v.20, p.179-186, 2004.

PHILLIPS, B.S.; KASS, P.H.; NAYDAN, D.K. et al. Apoptotic and proliferation indexes in canine lymphoma. Journal of
Veterinary Diagnostic Investigation, v.12, n.2, p.111-117, 2000.

ROBERT, M; FRIEDLANDER, M.D. Apoptosis and Caspases in Neurodegenerative Diseases. New England Journal of Medicine, v.348, p.1365-1375, 2003.

RYU, J.M.; KIM, A.D.; KANG, K.A. et al. The green algae Ulva fasciata Delile extract induces apoptotic cell death in human colon cancer cells. In Vitro Cellular \& Developmental Biology Animal, v.49, n.1, p.74-81, 2003.

SAPIÊNCIA. Jornal Informativo Científico da FAPEPI, n.23, p. 04-09, 2010. Disponível em: <http://www.fapepi.pi.gov.br/nova/sapien cia/pdf/sapiencia23.pdf.> Acesso em: 29/01/2015.

SMITH, M.E.; VAN DER MAESEN, K.; SOMERA, F.P. et al. Effects of phorbol myristate acetate (PMA) on functions of macrophages and microglia in vitro. Neurochemical Research, v.23, n.3, p.427-434, 1998.

SUZANO, S.M.C. Avaliação da proliferação celular, índice apoptótico e da expressão do p53 nos linfomas caninos. 2006. Botucatu, 73f. Tese (Doutorado em Medicina Veterinária) Faculdade de Medicina Veterinária e Zootecnia, Universidade Estadual Paulista.

THORMBERRY, N.A.; LAZEBNIK, Y. Caspases: Enemies within. Science, v.281, n.5381, p. 1312-1316, 1998.

TSAI, Y.; CHIU, C.; CHEN, J.Y. et al. Cytotoxic effects of Echinacea purpurea flower extracts and cichoric acid on human colon cancer cells trough induction of apoptosis. Journal of Ethnopharmacology, v.143, n.3, p.914919, 2012. 
VALE, V.V.; ORLANDA, J.F.F. Atividade antimicrobiana do extrato bruto etanólico das partes aéreas de Euphorbia tirucalli Linneau (Euphorbiaceae). Scientia Plena, v.7, n.4, 2011.

VARRICCHIO, M.C.B.N.; SILVA, S.; GOMES, N.B.N. et al. O Uso de Euphorbia tirucalli (Aveloz) em Medicina Tradicional e as Evidências Científicas. Revista de Biologia e Farmácia, v.3, n.1, p.84-92, 2008. 